The Beinecke Library of Yale University, edited by Stephen Parks (239 pages, February 2004), pays tribute to the collections, the staff, and the architecture of Yale's 41-year-old rare book library. Included are essays, by each of the Beinecke curators, on the collections' move from the Stirling library in 1963, early manuscripts and books, modem books and manuscripts, the American literature collection, the Osborn collection of English manuscripts, the German literature collection, Western Americana, and the music manuscripts. Beautifully illustrated with photos of the building and its treasures. Beinecke Rare Book and Manuscript Library. \$50.00. ISBN 0-8457-3150-5.

Care and Handling of CDs and DVDs: A Guide for Librarians and Archivists, by Fred R. Byers ( 42 pages, October 2003), offers advice on disc preservation, cleaning, storage, and longevity, and presents a guide to the basic structure of different types of CDs and DVDs. A glossary defines current abbreviations and jargon. Council on Library and Information Resources. $\$ 15.00$. ISBN 1-932326-04-9.

The Chronology of American Literature, edited by Daniel S. Burt ( 805 pages, February 2004), presents a year-by-year history of fiction, nonfiction, essays, poetry, drama, criticism, journalism, essays, diaries, religious writings, and awards published in the United States, from Hakluyt's Vyyages in 1582 to Edwin G. Burrows and Mike Wallace's 1999 social history of New York City, Gotham. Not just a list, this chronicle provides a summary and context for each work, and is divided into five major sections: the colonial period (1582-1789), nationalism and romanticism (17901860), realism and naturalism (1861-1914), the birth of modernism (1915-1949), and modernism and postmodernism (1950-1999). Houghton Mifflin. \$40.00. ISBN 0-618-16821-4.

Far more detailed is The Oxford Encyclopedia of American Literature, edited by Jay Parini (4 vols., February 2004), which contains some 350 essays

George M. Eberhart is senior editor of American Libraries, e-mail: geberhart@ala.org on U.S. literature from colonial times to the present. In addition to the 241 author biographies are close examinations of such works as Catcher in the Rye and A Raisin in the Sun and treatments of such major themes as Black Mountain poetry, the new formalism, and writing as a woman in the 20th century. Parini writes in the preface that he discouraged his essayists from using jargon and theorizing excessively, yet he asked them to place their subjects within the context of recent theory and literary practice. Oxford University. $\$ 495.00$. ISBN 0-19-516724-4.

Dr. Seuss: American Icon, by Philip Nel (301 pages, January 2004), thoroughly examines the poetry, art, and prose of Theodor Seuss Geisel

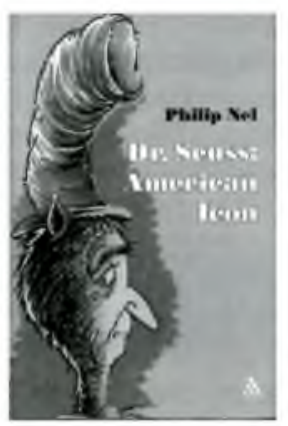

from several standpoints. Nel puts Seuss's nonsense verse in the same category as the best linguistic experiments of Lewis Carroll and Edward Lear, and argues that World War II transformed Geisel into America's first anti-Fascist children's writer, inspiring him to write such activist books as Horton Hears a Who!(1954), Yertle the Turtle (1958), and The Lorax (1971). Other themes studied are the influences on his artistic style, the posthumous repackaging of Seussiana by the corporation nun by his widow Audrey, and how Seuss characters have entered popular culture. Supplemented with a dense, 72-page, annotated bibliography. Continuum. \$27.95. ISBN 0-8264-1434-6.

Exploring Polar Frontiers: A Historical Encyclopedia, by William James Mills (797 pages, 2 vols., December 2003), is a treasure trove of information on expeditions to the Arctic and the Antarctic, from Pytheas the Greek's voyage to Ultima Thule in 325 B.C. to Børge Ousland's first solo crossing of the Arctic Ocean in 2001. Explorers and topics (such as cartography, means of transport, and expedition goals) are covered in detail, as well as the history of specific geographi- 
cal locations (Amund Ringnes Island and King Christian X Land, for example)- a useful feature that offers a different perspective from conventional exploration narratives. A glossary, timeline, bibliography, 20 maps, and numerous photographs enhance this impressive effort by Mills, who is librarian at the Scott Polar Research Institute at the University of Cambridge. ABC-CLIO. $\$ 185.00$. ISBN 1-57607-422-6.

\section{Gettysburg: Memory, Market, and an} American Shrine, by Jim Weeks (267 pages, April 2003), offers an unusual and controversial look at the town. Although known as a shrine to history and the reunion of North and South, the Gettysburg battlefield has always had a commercial side unlike any other Civil War memorial. A local studio was selling sets of photographic battlefield views as soon as five months after the battle, and the town has long been a magnet for museumgoers, souvenir-hunters, and, more recently, reenactors. Weeks charts the changing methods entrepreneurs have used to market Gertysburg as an educational attraction and the varied tourist experiences that have made it memorable over the years. (Full disclosure: I grew up in the town and my great-grandfather was a hotelier who encouraged the tourist trade at the turn of the last century, so I have seen both its sacred and profane aspects.) Princeton University. \$29.95. ISBN 0691-10271-6.

How Early America Sounded, by Richard Cullen Rath (227 pages, January 2004), reveals a long-forgotten sonic world of mystery and nuance that existed in 18th-century America. Our pre-industrial ancestors were acutely attuned to a tangible soundscape filled with harmony and dissonance, accent, and rhythm that is unavailable to us. Rath notes the significance of the sound of thunder, water, and wind in early America; the use of music in defining a community; the singularly sonorous qualities of colonial meetinghouses; the specific meanings of murmuring and ranting among Quaker communities; and the Native American concept of sound and utterance as embodied acts of identity. Comell University. $\$ 32.50$. ISBN 0-8014-4126-9.

The Kovacs Guide to Electronic Library Collection Development, by Diane K. Kovacs and Kara L. Robinson (251 pages, January 2004), gives advice on developing and maintaining a collection of Web-accessible information resources.
The authors suggest collection development principles, evaluation guidelines, selection criteria, and core collections for major subject areas. Scattered throughout the text are case studies of e-library collections at such institutions as the National Library of Medicine, the University of California-Riverside, and Iowa State University. NealSchuman. \$125.00. ISBN 1-55570-483-2.

Lie Detectors: A Social History, by Kerry Segrave (218 pages, February 2004), examines the shaky history of the polygraph-an instrument that records physiological changes in a subject and relates them to the truth or falsehood of responses to questions - and its use in law enforcement, security, and business. Although now largely discredited as an instrument of truth in the United States, it wasn't until 1988 that Congress passed a law prohibiting their use in employee screening by private firms, and ten years later the Supreme Court ruled polygraph results inadmissible in criminal cases. Segrave covers all this in entertaining detail, along with the early history of lie detectors, the explosion of their use during the Cold War, and a variety of recent inventions. McFarland. $\$ 36.50$. ISBN 0-7864-1618-1.

Segrave has written other titles in McFarland's series on social history, including books on jukeboxes (2002), vending machines (2002), shoplifting (2001), home movies (1999), tipping (1998), baldness (1996), and drive-in theaters (1992). In 2003, author William $\mathrm{E}$. Jarvis contributed a fascinating cultural history of time capsules, an activity that libraries often engage in; and Lewis Coe compiled a history of the telegraph in 1993, which McFarland is now offering in a reprint edition. See www. macfarlandpub.com for these and others.

\section{Shameless Exploitation in Pursuit of the Common Good, by Paul Newman and A. E.} Hotchner (260 pages, November 2003), tells the story of the authors' extraordinary luck and success in creating the Newman's Own line of salad dressings, popcorn, salsa, and other products, the after-tax profits on which go entirely to charity. Written in a zany style that matches their irreverent take on traditional marketing, the book dishes up as much humor as it does insight into the pair's antistrategies, accompanied by an account of how Newman started up his Hole in the Wall Gang camps for sick children. Nan A. Talese/Doubleday. \$23.95. ISBN 0-385-50802-6. 